\title{
Funny Walking: The Rise, Fall and Rise of the Anglo-American Comic Eccentric Dancer
}

\begin{abstract}
This article considers the (seemingly) lost art of comic eccentric dance. As a form of popular entertainment, comic eccentric dancing is generally assumed to be an early to mid-twentieth century phenomenon that emerged in the UK from the late Victorian Music Hall period and remained unchanged throughout the Variety period, only to disappear in the era of new mass media's lack of appetite for 'turns' and speciality acts. However, is comic eccentric dance really a lost performance form? Can incarnations of the form really be considered as obsolete and archaic as such routines as, say, mesmerism, blackface or budgerigar acts?
\end{abstract} This article will attempt to reposition comic eccentric dance as a metamorphic form that still, surprisingly, exists, and is to be found with reasonable ubiquity, in renewed incarnations within twenty first century media.

Tracing the origins of comic eccentric dance through examples of earlier comedy performance, and drawing from Bergson's comic theory of body misalliance, this article will discuss this particularly ludic fusion of music and comedy. Further changes to the form affected by modernist preoccupations during the new Jazz Age at the turn of the twentieth century will be suggested. Finally, ways in which the formulation lives on in twenty-first century incarnations in the comedy work of, for instance, Jimmy Fallon and Ricky Gervase, and in popular television shows such as Strictly Come Dancing (BBC 2004 - ) and Britain's Got Talent (ITV 2006 - ) will be posited.

\section{Key words - funny walks, eccentric dance, comedy, Bergson, Max Wall}

\section{Introduction: what is comic eccentric dance?}

As Dennis Kennedy states, 'dance may be defined as designed movement, or movement framed to be perceived as designed... [it is] part of every human culture' (2010: 154). Comic dance contains a discrete theatrical functionality in that it is specifically designed to lampoon aesthetically designed dance forms while aiming to evoke, predominantly, the laughter response in the spectator. Comic eccentric dancing is a theatrical form that relies on the performance of incongruous extremes. An extended version of funny walking, comic eccentric dancing involves the performer using movement that includes over-bent knees, sticking out of the hind quarters, and the execution of a series of shuffles, waddles, sways, jutting actions, sudden turns, kicks, changes of direction, and alternately tiny and huge steps, all of these presented in a seemingly arbitrary fashion.

By the mid twentieth century comic eccentric dance had become a staple part of the routines of certain comedians. Extant examples of their art can be seen online in the work of, say, Little Tich, Richard Hearne and George Carl. Throughout its hey-day during the first six decades of the twentieth century in the UK, comic eccentric dancing remained an eminently crowd-pleasing form of entertainment. As late as the 1970s the work of comedians who still employed comic eccentric dance in their routines could be seen on mainstream television in the UK. For example Hayward and Hayward write of the infinitely hysterical' comedian Billy Dainty, noting that 'it was not until 1974 that Billy's television 
career began, following his appearance in the Royal Variety Performance' (Hayward and Hayward 1993: 73).

Perhaps the most famous exponent of British comic eccentric dance was Max Wall (19081990), 'the boy with the independent legs' (Wall, 1975: 91). Wall's prowess emerged from his early variety training ground. He reported that his father, the comedian Jock Lorimer and 'Arthur Derry... an eccentric dancer who taught me a few steps' (Wall, 1975: 54). Wall regularly performed his 'Professor Wallofski' routine from the 1940s onwards in which, dressed in black tights, boots, a conductor's jacket and a bald wig fringed with lank black hair, he 'strutted ostrich-style around the stage' (Hayward and Hayward 1993: 236). An impressionistic description of Wall's eccentric dance as Wallofksy could roughly be characterised as follows:

To the accompaniment of a quasi-military 4.4 shuffle drum beat, Wall, with hands in jacket pockets, twistingly, gurningly, with his jaw jutting, kicks out his heels, knees protruding, crosses left, turns right leg over left, straightens legs, thrusts bottom further out, sweeps left to right, knees bent, swivels through 45 degrees, kicks height with right leg, winces in pain, grimaces, grabs crotch, continues hunched shuffle, steps on his own feet, continues with mincingly small steps, slowly getting smaller, moving round in circles.

From his earliest Variety days Wall became known as 'the boy with the educated feet' (Wilmut, 1989: 220). He persisted with the same act until he was well into his 70s. As Wilmut reports of seeing the routine in Wall's one man show in 1973, 'he finished with his trademark, the funny walk - a version of his old eccentric dance act, complete with high kicks (followed by an anguished clutch at the groin) and facial expressions reminiscent of a gorilla with toothache' (1989: 221).

\section{Figure 1: Photo of Wall's Autobiography (ㅇ I. Wilkie 2017}

There is no doubt that comic eccentric dance was a very popular form of entertainment in the Music Hall, reaching its zenith in Variety in which comic eccentric dance routines proliferated (celebrated exponents being, for example, Wilson, Keppel and Betty and their fauxEgyptian sand dances, Cicely Courtneidge's mock adagio, Richard Hearne (as Mr Pastry dancing The Lancers) or Denny Willis and the Quorn Quartet. The physicality of an act such as Denny Willis and the Quorn Quartet traded on incongruity and parody of the 'designed movement' of the choreographed song and dance routine. Denny Willis (1920-1995), like Max Wall, was the son of a working comedian. Denny Willis, like his father, Dave Willis, also toured in Variety, latterly appearing internationally on television, repeating his popular act across Europe for over twenty years. In his Quorn Quartet routine, Denny Willis appeared as a diminutive, white-haired individual sporting a pince-nez and dressed in an over-large, red, hunting-coat (complete with an outsized, Harry-Hillesque shirt collar). Willis was accompanied by three taller and stockier sidekicks, all of whom were impeccably dressed in tailored and contrastingly, well-fitting red hunting gear. The dishevelled Willis would then attempt to join in a knockabout hunting song, complete with actions. The semiotics of the clothing choice hints at a swipe at both Englishness and 'upper class-ness' in the caricature of the hunting garb, with (the Scottish) Willis clearly functioning as the 'outsider' - but nonetheless as the most complicit and closely identifiable figure in the routine. In the process of the 
number, the comedian would be dramatically lifted off his feet; lose his shoe; be continuously hit in the face; his pince-nez would become dislodged; and he would end up crawling about on his hands and knees. All the while, the deadpan and impassive huntsmen would resolutely continue to sing and perform what was, in fact, a somewhat nonsensical and childish song (an adaptation of the old revue song The Fox Has Left his Lair):

The hunting huntsman blows his horn...

Old grandpa with his wooden leg, limping, limping.

Ha ha ha ha ha ha ha ha, silly, billy.

The children running home from school, he's barmy, he's barmy.

All for the Lady Gwendoline, she's charming, she's charming ((Denny Willis'

adaptation of The Fox Has Left His Lair from The Charlot Revue: 1925).

\section{Figure 2: Photo Denny Willis ㄷ I. Wilkie Collection 2017}

On film, meanwhile, in both the U.K. and the U.S., comic eccentric dance routines became a recognised element within the exegesis. The early screen clown Charlie Chaplin brought his own version of comic dance from the British Music Hall to his Hollywood films. Significantly, Chaplin notes in his autobiography that, aged 12 , in his impoverished south London boyhood, he made his household contribution 'of five shillings weekly which I earned giving dancing lessons' (1964: 2). Similarly, Stan Laurel imported a music hall dance ability which is reflected in Laurel and Hardy's film routines in, say, Bonnie Scotland (Horne, 1935) and Way Out West (Horne, 1937). A funny dancing sensibility appears in all the routines in the duo's films which, as Halliwell claims, creates an overall 'comic ballet' (1987: 130). Later variations of comic dance routines would feature in America in the films of Ray Bolger, Martha Raye, Donald O'Connor, Gilbert Lamb and Buddy Ebsen. In the UK the cinematic showings on Pathe Pictorial of the 'original screwy dancer', Jack Stanford, evidenced a domestic public appetite for the form.

That eccentric dance was widespread in popular culture generally at this time can be seen in intriguing existing footage from an amateur Dance competition in France dated 1931, in which a group of young men, compete in a display of eccentric dance, incongruously dressed in smart, formal dress clothes and hats, in a style which, in fact, foreshadows end of century hip hop and street dance styles. (The video can be found online by entering 'A French Dance Contest 1931' and following the 'Vintage Swing Dance' video share postings). Here, the form has clearly reached a social and cultural apogee, lodged in contemporary popular consciousness and functioning in a unified manner where dance represents 'games, sport, combat, psychological and physiological therapy, or social, cultural and political event' (Kennedy: 2010: 154).

\section{Why is comic eccentric dance funny?}

But why is eccentric dancing funny?

As Horst Ruthrof points out in Semantics and the Body, communicative meaning is made through bodily acts. What we do conveys more meaning than what we say, particularly 'the more ludic, or playful, the discourse' (1997: 40). He adds, 'we recognize the unexpected 
world that we are forced to construe... as a comical extension of the world we know. What is funny is not a formal or verbal alternative but a corporeal one' (1997: 40).

Eccentric dance conjures up an unexpected world, one that is both parodic and anarchic. It challenges the 'correct' way of dancing and embraces the grotesque, absurd and excessive. It is designed, to a large extent, to amuse or make the spectator laugh in a way that most other forms of dance, are not.

Eccentric dance also follows the Bergsonian principle of comedy in that it demonstrates 'mechanical inelasticity' (1911: 20); 'it enables us to see man as a jointed puppet' (1911: 30) and illustrates 'the divers attitudes, capers, and movements which form the strictly "clownish" element in the clown's art' (1911: 58). This essential principle of incongruity is at the heart of the apperception of 'the origins of comic performance in adult-child interaction' (Wilkie and Saxton, 2010). As Greig further notes of the essentially childhood-located appeal of comic eccentric dance, it is incongruous in its execution (as here, in the use of a toy):

It may be true that children get fun out of the dancing jack... because... it dances...not in the way children are accustomed to, not as human beings dance, with a certain attempt at regularity and smoothness of rhythm, but jerkily, unaccountably, irregularly (Greig, 1923, 1969: 140).

Comic dance is also incongruous in the perception of sheer unexpectedness in the distorted actions, sudden turns, awkward thrusts and jutting movements - and also in the basic surprise afforded of a 'non-dancer' dancing (or a skilful dancer dancing in an unexpected way). The performativity of the action is also important in creating the meaning, as the audience is complicit in responding accordingly to an activity that is produced with the intention that it is to be received as amusing.

As a pure dance form (rather than a comic form), 'straight' eccentric dancing is nonetheless, described by the dance critic Beverley Fletcher as 'embrac[ing] comedic movement; odd or individual interpretation; and all styles and presentations that are of a non-conforming nature. It may be as subtle as a Chaplin or as blatant as a circus clown' (2002: 28). What makes it funny in the purely comic version is, as in any act of essential clowning/physical theatre, that as John Wright notes, the 'audience/spectator transaction' (2007:85) pleases us, especially if it is evidently executed with some degree of 'skill' of expertise (Auden, 1952: 373). Here, W.H. Auden's notion of the 'clumsy man' pertains:

In appearance, he is the clumsy man whom inanimate objects conspire against to torment; this is in itself funny to watch, but our profounder amusement is derived from our knowledge that this is only an appearance, that, in reality, the accuracy with which the objects trip him up or hit him on the head is caused by the clown's own skill (1952. In Enck et al, 1960: 373).

In the case of Max Wall, his garb as Wallofski emphasises the serious 'balletic' nature of the enterprise undercut by his deceptively skilful 'incorrect' movement and actions. This is the conscious display of intercommunicative, representational skills which the actor is able deploy to cause an effect, specifically, in this case, in the doing of comedy. The performer's expertise - i.e. how well this comic mini-drama is interpreted and performed by the actor - is 
crucial to our enjoyment. As Brett Mills notes of the importance that the performer's expertise plays in successfully delivering the overall message - 'for comic performance to offer pleasure it must demonstrate the abilities of the person performing it far more obviously than non-comic forms do' (2005: 70). So, eccentric dancing is funny because, as in any performance transaction where the comedy performer is responsible for making the event comical, it crucially requires expertise for it to be truly funny. Thus the funny walk's apotheosis is, arguably, that of John Cleese in his Monty Python 'Ministry of Silly Walks' (BBC: 1970). It combines incongruity in a comically eccentric dance that is expertly executed in a routine that has become seared into popular consciousness - one that remains timeless, and essentially and universally funny.

\section{Origins of Comic Eccentric Dance}

The genesis of comic dancing can be traced back to the origins of all performance, i.e. emanating from primitive rituals and rites. Comedy emerged out of celebrations of venal fertility. As Clive Unger-Hamilton notes, 'the songs and dances that inspired it emphasized ribaldry more than ritual' (1980: 11). These dances became formalised in Classical Greek Drama through the Dionysia and then in Attic theatre in which:

The comic dance was called the kordax. Its movements were coarse and lascivious and its general style was suggestive of the phallic songs out of which comedy had been developed. It was a dance for drunken people... in the comic dances the wildest movements were admissable (Haigh, 1898: 355-356)

This eccentric dance appeared centrally in the Satyr Plays:

Silenius:

Now will you please obey me, and not dare

To kick your silly legs up in the air?

Satyrs:

Of course we will, but what about the sound?

It faded when we started dancing around (Sophocles, c. 440 BC, 1957: 65).

From the earliest comic dance figures that exist we can see the principle of superiority being centrally played out in those contemporaneous incarnations of comic expression, wherein Plato posited that comedy mixes 'malice with 'laughter' (1997: 10). Aristotle noted that 'comedy is...an imitation of characters of a lower type....t consists in some defect or ugliness which is not painful or destructive' (1987: 9). This principle is clearly seen in the creation, affects and effects of the 'comic' eccentric dancer below.

\section{Figure 3: Reproduction Drawing of C 1 AD Roman Bronze Comic Dwarf Dancing Figure (C Gordon McKendrick 2017}

Comedians dancing for humorous effect can continue to be traced through history. By the middle ages, 'court festivals and entertainments reaching back to the processions and mummeries of the Middle Ages' (Au, 2012: 11) were in vogue while Commedia's theatricalities contributed to popularising the form, with morris (and, later, clog) dancing becoming subsidiaries of the form in the U.K. Grimaldi, 'the great Clown of the English pantomime... was the son of a dancer, who was nicknamed 'Iron Legs', and he was determined that his son should follow in his footsteps' (Lathan, 2004: 33). When Will Kemp, 
Shakespeare's most famous clown, danced the morris from London to Norwich in 1599, his 'performance of the jig' (Dyce, 1860: v) summed up eccentric dance at its zenith. This was an instance of a famous comedian of the day using dance to express comic artistry with some degree of clownish expertise and is very much in the tradition of how comic eccentric dance of the twentieth century and beyond is articulated. Through John Harper (an eighteenth century Falstaff) who 'first made his name with a drunken man dance at Southwark Fair in 1715' (Thomson, 2000: 49) the activity remained popular and eventually permeated into Music Hall and then into Variety in the UK and Vaudeville in the U.S.

The first professional comedy form, moreover, the Commedia dell' arte, featured comic dance forms which are still to be seen in the spoof dance balloon dance of modern pantomime (Marshall in Abbott 2012: 218). This, in turn, morphed again into the bawdry of the balloon dance routine of anarchic, neo-Dadaist anarchist cabaret comedian Malcolm Hardee and his South London comedy troupe The Greatest Show on Legs:

All three of us, stark naked except for socks, did the cha-cha while holding two balloons each and swapping them round on the fourth beat to cover our genitals...we also tap-danced with dustbin lids on our feet, and we did a Scottish sword-dance using members of the audience instead of swords (Hardee, 1996: 105).

The comic eccentric dance that emerged from earliest performance phenomena, becoming reshaped during professionalised forms of theatrical expression throughout the ensuing centuries, made its way into Music Hall, and thence into musical comedy. Max Wall noted that 'Lupino Lane [as a butler was the] first to introduce music hall tumbling into musical comedy' (1975: 120-121). Eccentric dance had become legitimate.

\section{Twentieth Century Comic Eccentric Dance}

The next primary influence on comic eccentric dance - and what helped propel variations into the mass media mainstream in the twentieth century was the modernist preoccupation with the new jazz wave in the early part of the first two decades. A major influence on the form was, as Brian Harker notes, the music of jazz as a brand new genre - itself a hybrid of vaudeville and the experimental style innovations from Black music clubs of New Orleans reappropriated in turn by the growing 'nightclub culture' in the cities of the United States. Together these strands meant that eccentric jazz dance became a socio-cultural fixture by 1915 (Harker, 2008:24). The comic and Vaudevillian 'eccentricity' element had arisen through the input of African and exotic dancers riffing on traditional styles of clog and tap dancing in theatrical presentations of the new jazz form. The addition of acrobatics, displacement, agility and exaggeration, along with 'a humorous rather than a serious intention' (Gordon, 1996: 424) kept the fun element of jazz dance to the fore at this time. Meanwhile the apparent unorthodoxy, novelty and playing with form meant that the sound of jazz music, too, was initially viewed as a comic genre. From the new jazz dance that accompanied the avant-garde music, particular styles emerged. The terms 'rubberlegs' or 'legomania' became current (Fletcher, 2008: 28). The innovative moves were based on the execution of 'high kicks', 'wiggles' and 'shimmies'. As Stearns and Stearns noted of dancers of the period, 'the term 'eccentric' is a catchall for dancers who have their own nonstandard movements and sell themselves on their individual styles' (1964, 1979: 232). Moreover, in their account of 1920's cotton club dancer Earl "Snake Hips" Tucker, the Stearns outline 
many precursors that can be seen in Max Wall's later and more overtly comic 'Wallofski' dance:

He came slipping on[stage] with a sliding, forward step. ... Using shock tactics, he then went directly into the basic Snake Hips movements, which he paced superbly, starting out innocently enough. ... As he progressed, Tucker's footwork became flatter, rooted more firmly to the floor, while his hips described wider and wider circles, until he seemed to be throwing his hips alternately out of joint to the melodic accents of the music... . The next movement was known among dancers as the Belly Roll, and consisted of a series of waves rolling from pelvis to chest-a standard part of a Shake dancer's routine, which Tucker varied by coming to a stop, transfixing the audience with a baleful, hypnotic stare, and twirling his long tassel in time with the music (1964, 1979: 236).

The influence of the jazz age on modernism was considerable and so further crossover into artistic and highbrow culture was, perhaps, inevitable. Eccentric dancing was reclaimed in more serious and academic circles as an area of interest and began to be incorporated into less purely ludic and overtly playful forms of performance expression. For instance, by 1912, the Ballet Russe was already including what it understood to be eccentric dance forms within its repertoire, drawing upon what David Cleall describes as 'the exciting contemporary collision between popular dance, ragtime jazz and the visual arts' and as was depicted in the the cubist William Roberts' 1914 artwork The Toe Dancer (Cleall, 2015).

In Moscow, by the 1920s, jazz influences were firmly embedded in serious Soviet dance modes. Practitioners such as Valentin Parnakh and Kasian Goleizovsky appropriated the term 'eccentric dance' to refer to their own usage of high culture balletic artistry which relegated the self-consciously parodic, free form and free expression elements of the jazz clubs into the background. These influential choreographers pursued a different ethos by making apparently 'incorrect' dance moves become the correct means of expression within a fashionably avant-garde theatre. Eccentric dance thus began to morph during this period into high art cabaret dance formulations. As Mel Gordon notes:

Parnakh's entry into the avant-garde circles of Moscow in the fall of 1922 was as vigorous and manifold as his art form. He published three articles on Eccentric Art, Charlie Chaplin, and the Mimetic Orchestrae in the inaugural issues of the trade newspaper Zrelishcha; he taught an "Eccentric Dance" class for Ippolit Sokolov's new studio, the Laboratory of the Theater of Expressionism... he gave lessons in the foxtrot for the Moscow Proletkult; and he introduced live jazz to Russia with his "First Eccentric Orchestra of the Russian Federated Socialist Republic." The first of two public concerts was given in the State Institute for Theatrical Art on October 1, 1922 and created the stir that Parnakh needed (Gordon, 1996: 427).

In appropriating jazz movement styles into cabaret dance and ballet, Parnakh, a veritable soviet dance apostle, favoured the use of 'disembodied gesticulations' and, as Mel Gordon further notes, for his work, 'the seemingly improvised gestures of the jazz Kings represented something more than amusing physical banter, they would be the basis of a new art form, the Eccentric dance' (1996: 424). 
Fellow Russian dance guru, Kasan Goleizovsky, meanwhile, 'create[d] unusual effects by his intricate intertwining of arms and legs' (Chernova 1996: 28) while, simultaneously, 'a new task had preoccupied the choreographer. In the spring of 1923 a series of "eccentric" dances emerged: a foxtrot, a two-step and a tango, which Goleizovsky "reshaped" and "reworked imaginatively"' (Souritz, 1990:67). As Chernova further outlines, contemporary critics were appalled by Goleizovsky's innovations, lamenting that his:

Undisguised circus acrobatics, reminiscent of cafe-chantant clowning around, when carried over into the arena of artistic drama, elicit only disgust.... A pair of dancers fall onto their backs with legs raised upwards to create a bas-relief effect while holding onto the legs of a dancer who is lying on the floor, forming the shape of a backwards $\mathrm{N}$.

And,

[The dancers) find an unnatural bend for every joint in the body. Eccentricity is intensified by acrobatic tricks that dislocate the natural development of a movement. The leg is ascribed the unusual function of being an independent, expressive element rather than a support for the body. In order to free the leg, the body is hurled onto the stage or even used as a support for the leg. The leg "gesticulates." (1996: 381410).

Also, by the 1920s the soviet artist and director Nikolai Foregger had introduced eurythmics, circus and commedia and music hall elements into the cabaret and ballet dance mainstream, noting the inclusion of the Bergsonian comic principle apropos his Mechanical Dances (1923) in that 'we view the dancer's body as a machine and the volitional muscles as the machinist '(Goldberg, 2001: 37-40).

In the world of Art, the French Dadaist Francis Picabia introduced eccentric ballet dancing into his early film experiments. This was intended to be comic. 'Picabia himself once asserted that Entr'acte "respects nothing except the right to roar with laughter"' (Crow, 2014). Repositioning the comic potential of eccentric dance within high art formulations reminds us that, as in much conceptual art, the purely 'vaudeville' nature of many of these more surrealistic art events mean that they teeter precariously on the edge of being pure comic performance in themselves. Indeed there was notably 'a strain of Vaudevillian comedy... apparent in early twentieth century art movements in the work of the Futurist's 'Theatre of surprise' (Goldberg 2001: 29); through Dadaist 'hoaxes' (Goldberg 2001: 90) and 'ballets' such as Parade (1917) (Goldberg 2001: 77)' (Wilkie, 2013: 220).

This, in turn, returns us to the popular appeal of comic eccentric dance that consequently distances it from any high art appropriations. Yet, is it the assumption that the Vaudeville/Variety age popularity of the routines renders the form moribund and inevitably locked in performance presentations of the period? Is it a lost art form that has now disappeared from popular consciousness? What, if anything, do we see of it today?

\section{Twenty-First Century Comic Eccentric Dance}


Finally, any presumption that eccentric dancing is a moribund form proves erroneous. In wider culture, comic eccentric dance can be discovered in numerous guises. It has, for example, been appropriated in pop music. Talking Heads' 1981 video for One in a Lifetime saw David Byrne dancing jerkily and spasmodically while dressed in a suit, spectacles and bow tie. In the video for Praise You by Fat Boy Slim (1999), Spike Jonze featured as 'Richard Koufey' along with the fictitious 'The Torrance Community Dance Group' performing odd semi-synchronised urban street dance, filmed guerrilla-style. Psy's 2012 mega-hit Gangnam Style became seared into the public imagination by the singer's execution of his muchsampled 'invisible horse dance'. As the writer of the website Readwrite notes, 'we reported that Psy's Gangnam Style was the first video to reach a billion views, and the viral hit is standing strong at number 1 and has reached the coveted 2 billion view mark' (readwite.com, posting Sept 2 2012).

A thread of eccentric dance (sometimes incorporated for deliberately comic and incongruous effect) permeates the Modern and Contemporary Dance milieu. From Merce Cunningham's radical play with non-coordination of associated music and movement; through to Bob Fosse's Giacometti-like figures brought-to-life in the 'frug' dancing in Sweet Charity (Fosse: 1969); through Matthew Bourne's harness of incongruity and role-play in his pieces; to DV8's risk-taking with the perceived limitations of modern dance - an emphasis on oddness, violation of expectation and latitude towards the orthodox can be detected. In Art - and particularly in Performance Art - comic eccentric dance has often appeared as a trope. In the art work of Sam Taylor Wood, for example, her video Brontosaurus (1994) features a naked man dancing manically to a classical music track instead of the technojungle music along to which he was actually moving at the time. Spartacus Chetwynd, now known as Marvin Gaye Chetwynd, created a 2010 piece entitled 'The Cat Bus' in which she and her fellow performance artists provided a Happening in which:

Accompanied by a chamber orchestra recreating seal music, they perform mime and dance routines in order to compete for the glory of a ride on 'The Cat Bus', a character brought to life from Studio Ghibli's anime film, Totoro My Neighbour. The spirited event incorporates Chetwynd's interest in amateur performance, handmade costume, and a number of conflating influences, ranging from Mae West to John Waters, via Doris Lessing and the Marx Brothers (Frieze, 2010).

Contemporary manifestations in more overtly popular entertainment media are many and the idea of comedian dancing, or non-dancers dancing for comic effect, lives on.

Reinventions of the form are to be found in numerous contemporary performance outlets. Throughout the Internet's life, new incarnations include, firstly, online remixes of original footage of comic eccentric dancers. The routines of Max Wall, for instance, can be viewed on YouTube variously remixed (to still valid comic effect) as Wall is seen to perform his eccentric moves to a soundtrack of disco, skank, Ibizan chill-out and post-punk, Indie revival rock music. Secondly, recreations of the sand act dance of Wilson Keppel and Betty can also be found (through an Internet search of video hosting sites containing their details) and versions of their routine being performed by amateurs in talent shows, office parties, weddings and pantomimes are plentiful. The expertise and precision that made the original dance so delightfully incongruous and comically irresistible is, however, often lacking in the tribute versions as if to point up the skill that is needed to be able to perform comic 
eccentric dance to full effect. As recently as 2015 the comic actors Matt Berry and Harry Peacock consciously recreated the original sand dance act (albeit for more overtly ironic purposes in their characters of Steven Toast and Ray Purchase) in the TV series Toast of London (Channel 4: 2012 - Season 3, Ep 4).

\section{Figure 4. Picture by Gordon Reproduction Drawing of Wilson, Keppel and Betty's Original Sand Dance (C) Gordon McKendrick 2017}

Contemporaneously, video sharing sites also host a surprising amount of incarnations of twenty-first century comic eccentric dance. As Walker noted in 2009, 'YouTube (created in 2005) is the variety show writ large' (Walker, 2009: 12) and so it is hardly surprising that the Variety tradition lives on in the content of the virtual realm. Readwrite.com noted that Judson Laipply's 2001 Evolution of Dance video (in which American comedian named Judson Laipply performs an extended eccentric dance mash-up routine, which exhibits incongruity, endurance and a comic expertise that is directly in the tradition of Max Wall - or even, arguably, Grimaldi or Kemp) had, for its time, achieved a record number of hits - 'we first did this list in August 2007, at which point Evolution of Dance by comedian Judson Laipply was number 1 with nearly 56 million views' (readwite.com, posting Sept 2, 2012). At the time of writing (May 2017) Laipply has almost 300 million hits logged on the version of the video posted to his own site. The endurance and expertise element involved in Laipply's dance marathon is reminiscent of the British stand-up comedian Eddie Izzard's 2009 undertaking of 43 marathons in 51 days and, in 2016, 27 marathons in 27 days. This is an instance of the contemporary celebrity comedian performing feats of improbable endurance like Kemp's 'great journey' (Dyce, 1860: ix). Kemp, in his 'nine days wonder', covered 100 miles in a morris dance (albeit spread over several weeks).

If YouTube and other video sharing sites provide the platforms for new Variety forms, terrestrial television also capitalises on revitalised acts and routines from the past and, so inevitably, perhaps, comic eccentric dance does feature in the mainstream schedules. In the UK, Strictly Come Dancing (BBC: 2004- ) (known in the US as Dancing with the Stars (ABC: 2005 - )) enjoys enormous popularity and franchised versions appear in another 50 countries. In the programme, a clutch of celebrities, often clearly unsuited to the physical exigencies of ballroom dancing, are deliberately added to the mix to perform dance (badly) for public amusement. In the UK, politicians such as Ann Widdecombe and Ed Balls and the journalist and broadcaster John Sergeant have committed versions of comic eccentric dance to the record and in the US the likes of Steve Wozniak, the inventor and co-founder of Apple, and presenter Jerry Springer have elected to perform similarly. Here, the comic principle of superiority, where we are invited to laugh 'at' someone, rather than 'with' (as in the example of the classical figure at fig 1 above) seems, somewhat, dangerously, to pertain. However TV incarnations of eccentric comic dance also occur where the principle of incongruity is more evident, i.e. where we laugh with the performer, rather than at them. The principle of incongruity seems to predominate in cases where the expertise skills required for true eccentric dancing are allowed to prevail. For example, in talent shows such as Britains Got Talent (ITV: 2006 - ), itself another variety talent show format similarly spunoff and franchised to 58 countries, showcases acts such as Stavros Flatley or 'Old Men Grooving' who are clearly and firmly in the tradition of comic eccentric dancers of the past. They exhibit comic dance skills performed with a precision and spirited brio which, in turn, 
invites the spectator to laugh along with them and to be complicit in enjoying their abilities.

In the question of the comedy of superiority versus the comedy of incongruity, it is perhaps notable that one of the best remembered moments from the UK version of The Office (Gervase and Merchant, BBC: 2001-2003) is, as Ben Thompson writes in Sunshine on Putty,:

The already legendary scene....where Brent endeavours to trump his suave...new boss's exquisitely well-delivered John Travolta dance routine by improvising his own nightmarish assemblage of acid-house and break dance moves. As Brent flails around - haplessly but with absolute conviction - daring anyone to break the spell, he becomes a kind of human Catherine wheel, illuminating the Slough of despond (2004: 416).

Despite the series' overarching comic ethos of ironic cringe comedy (Hall, 2006: 12-13) it is Brent's eccentric dance sequence that cuts through and resonates, rendering the spectacle of Brent at his most human, vulnerable - and funny.

Other mainstream television incarnations are apparent. In the U.S. The Tonight Show with Jimmy Fallon (NBC, 2014 - ) regularly features dance battles and sketches involving comic dance (for example, 'The Evolution of Hip Hop' with Will Smith, 'The Evolution of End Zone Touchdowns' with Justin Timberlake, 'Come Dance With Us' with Jennifer Lawrence and 'Mom Dancing' with Michelle Obama). The potential of eccentric comic dance is too irresistible for programme-makers to ignore. It contains the essence of comic incongruity in the possibilities offered through the unexpectedness of the non-dancer dancing or the irresistible wrongness of dance being performed both badly and/or surprisingly well at one and the same time.

In conclusion, comic eccentric dance remains viable as a discrete and specialised form of clowning and the incongruities involved in it have a timeless appeal. Rather than merely being a dance form that uses comedy it might, in some senses, epitomise the purest form of comic expression. As Susanne Langer says, 'the human life feeling is the essence of comedy' (1953. In Romanska and Ackerman, 2017: 271). Just as laughter is an essentially human quality, to dance is to express essentially primal human behaviours. The dancer Martha Graham wrote 'I feel that the essence of dance is the expression of man - the landscape of his soul. I hope that every dance I do reveals something of myself or some wonderful thing a human can be' (1952. In Carter and O'Shea, 2010: 96). Perhaps the epitome of comic eccentric dance's inartistic yet skilful, exaggerations that are joyful to behold are apparent in the online video entitled 'Funny Old Guy Dancing' (viewable by typing 'Funny Old Guy Dancing' into the search engine). In the clip a very old man, at what appears to be a wedding, throws away his crutches to perform a surprisingly agile and spirited series of dance moves, so wrong that they become absolutely right. In the moment of the dance the 'old guy' becomes, gloriously and unashamedly, Everyman. 


\section{References}

Abbott, Chris (2012) Putting on the Panto to Pay for the Pinter: Henry Marshall Pantomimes at the Salisbury Playhouse 1955 to 1985, Salisbury: Hobnob Press

Aristotle (1997), Poetics, London: Dover Publications Ltd.

Au, Susan (2012) Ballet and Modern Dance, $3^{\text {rd }}$ edition London; Thames and Hudson Auden, W. H. (1952), "Notes on the Comic". In Thought, XXVII (Spring 1952). In Enck, John J., Forter, Elizabeth T., and Whitley, Alvin (eds) (1960), The Comic in Theory and Practice, New York: Appleton-Century Crofts.

Bergson, Henri (1911) Laughter: An Essay on the Meaning of the Comic, London: MacMillan and Co Ltd.

Carter, Alexandra and O'Shea, Janet (eds) (2010) The Routledge Dance Studies Reader, second edition, Oxon: Routledge (pp 95-100)

Chaplin, Charles (1964) My Autobiography, London: Bodley Head

Chernova, Natalia (1996) Kasian Goleizovsky and Eccentric Dance, Experiment, Volume 2, Issue 1 pp 381-410

Cleall, David (2015) An English Cubist: William Roberts, Modernism and Dance, William Roberts Society Newsletter, January 2015 Accessed online at:

http://www.englishcubist.co.uk/modernismanddance.html

Crow, Jonathan (2014) Entre'acte Rene Clair's Dadaist Masterpiece (1924) in Art Film, Nov $14^{\text {th }} 2014$

Accessed online at:

http://www.openculture.com/2014/11/entracte-rene-clairs-dadaist-masterpiece-1924.html Dyce, Alexander (1860), Kemps Nine Daies Wonder: Performed in a Daunce, London: John Bowyer Nichols and Son.

Enck, John J., Forter, Elizabeth T., and Whitley, Alvin (eds) (1960), The Comic in Theory and Practice, New York: Appleton-Century Crofts.

Fletcher, Beverly. Tapworks: A Tap Dictionary and Reference Manual, 2nd Edition. Princeton, N.J.: 2002.

Frieze Catalogue 2010. A live competition for the glory of a ride on 'The Cat Bus'

Accessed online at:

https://frieze.com/fair-programme/spartacus-chetwynd

Goldberg, RoseLee (2001) Performance Art from Futurism to the Present London: Thames and Hudson

Gordon, Mel (1996) Valentin Parnakh, Apostle of Eccentric Dance, Experiment, Vol 2 (1), pp 423-441.

Graham, Martha (1952) I am a dancer in Carter, Alexandra and O'Shea, Janet (eds) (2010)

The Routledge Dance Studies Reader, second edition, Oxon: Routledge (pp 95-100)

Greig, J.Y.T. $(1923,1969)$ The Psychology of Laughter and Comedy, New York, Cooper Square Publishers, Inc

Haigh, A.E. (1898) The Attic Theatre: A description of the stage and theatre of the Athenians, and of the dramatic performances at Athens, Oxford: Clarendon Press

Hall, Julian (2006), The Rough Guide to British Cult Comedy, London: Rough Guides Ltd. Halliwell, Leslie (1987) Double Take and Fade Away, London: Grafton Books 
Hardee Malcolm (with John Fleming) (1996) I Stole Freddie Mercury's Wedding Cake, London: Fourth Estate Ltd.

Harker, Brian (2008) Louis Armstrong, Eccentric Dance, and the Evolution of Jazz on the Eve of Swing,

Journal of the American Musicological Society 61.1 (Spring 2008): 67-121,242.

Accessed at:

https://business.highbeam.com/437059/article-1G1-178448713/louis-armstrong-eccentricdance-and-evolution-jazz

Hayward, Anthony and Hayward, Deborah (1993) TV Unforgettables: Over 250 legends of the Small Screen, Enfield, MX: Guinness Publishing Ltd.

Kennedy, Dennis (ed.) (2010) The Oxford Companion to Theatre and Performance, Oxford: Oxford University Press

Langer, Susanne, (1953) 'The Comic Rhythm' from Feeling and Form. In Romanska, Magda and Ackerman, Alan (2017) Reader in Comedy: An Anthology of Theory and Criticism, London; Bloomsbury

Lathan, Peter (2004) It's Behind You: The Story of Panto, London: New Holland Publishers (UK)

Marshall Henry (2012) Henry Marshall's Gag Book in Abbott, Chris (2012) Putting on the Panto to Pay for the Pinter: Henry Marshall Pantomimes at the Salisbury playhouse 1955 to 1985, Salisbury: Hobnob Press

Mills, Brett (2005) Television Sitcom, London: BFI Publishing

Plato. Republic 388e. Philebus 48-50. In Morreall, John (ed.) (1987), The Philosophy of

Laughter and Humor, New York: Albany.

Readwite.com. Accessed at:

http://readwrite.com/2012/09/02/top 10 youtube videos of all time/

Romanska, Magda and Ackerman, Alan (2017) Reader in Comedy: An Anthology of Theory and Criticism, London; Bloomsbury

Ruthrof, Horst (1997) Semiotics and the Body: Meaning from Frege to the Postmodern, Toronto: University of Toronto Press

Sophocles Ichneutai. In Green, Roger Lancelyn (1957) Two Satyr Plays, Harmondsworth, Penguin

Souritz, Elizabeth (1990) Soviet Choreographers in the 1920s, London: Dance Books Ltd. Stearns, Marshall and Stearns, Jean (1964, 1979) Jazz Dance: The Story of American Vernacular Dance, New York, Schirmer Books

Thompson, Ben (2004) Sunshine on Putty: The Golden Age of British Comedy from Vic Reeves to The Office, London: Harper Perennial

Thomson, Peter (2000), On Actors and Acting, Exeter: University of Exeter.

Unger-Hamilton, Clive ed. (1980) The Entertainers, London: Pitman House

Walker, Tim (2009), "Cowell's reality circus espouses British talent for eccentricity". Article in The Independent newspaper, 26/05/2009.

Wall, Max (1975) The Fool on the Hill, London: Quartet.

Wilkie, lan and Saxton, Matthew (2010), The Origins of Comic Performance in Adult-Child Interaction. Comedy Studies. Vol 1, Issue 1. Jan 2010, Intellect Ltd. Pages 21-32. Also in Sciama, Lidia (ed.) Humour, Comedy and Laughter: Obscenities, Paradoxes, Insights and the Renewal of Life, Oxford: Berghahn Books

Wilkie, Ian (2013) Vaudeville Comedy and Art, Comedy Studies, Vol. 4, Issue 2, Taylor and Francis Ltd. Pages 215-229 
Wilmut, Roger (1989) Kindly Leave the Stage! The Story of Variety 1919-1960 London: Methuen

Wright, John (2007), Why Is That So Funny? New York: Limelight.

This article is a version of a paper given at The TAPRA conference (popular performance group) in 2016.

\section{Biographical Notes:}

Dr lan Wilkie is a lecturer in performance at the University of Salford. He teaches comedy writing and performance, critical and textual studies and performance in context. He is editor of Comedy Studies and is the author of Performing in Comedy: A Student's Guide, Routledge, 2016.

\section{Contact details:}

E-mail: I.Wilkie1@salford.ac.uk

School of Arts and Media,

Room 6:02

New Adelphi Building

Peel Campus

University of Salford

Manchester M5 4WT 